\title{
STANDARD SETTING ON PESTICIDE RESIDUES TO ENSURE FOOD SAFETY
}

\author{
J iwan Prava Lama (MSc Food Technology) $)^{12}$
}

\begin{abstract}
This article highlights some aspects of pesticides contamination in foods and the Government of Nepal's experience in setting MRLs of pesticide on Food. Use of pesticides in agriculture crop has a great concern to all. According to the provision conferred by Food Law, Government of Nepal fixes MRLs of pesticide on food products. Potential products liable for pesticide use gets priority in standard setting. The problem of pesticides begins at the farm level and continues at different stage of handling and storage. Therefore, effective coordination between stakeholders working with different stages of food handling must collaborate to solve this problem. In this connection, some major issues and recommendations in managing proper use of pesticides are highlighted.
\end{abstract}

Key words: Pesticides, maximum residue limits (MRLs), Food safety and quality

\section{INTRODUCTION}

Pesticides are chemical substances defined as poisons and used in certain circumstances to kill specifically targeted pests (Wassemann, 1972). These highly stable compounds can last for years and decades before breaking down. They circulate globally, and persistent pesticides released in one part of the world can be transported through a repeated process of evaporation and deposit through the atmosphere to regions far away from the original source (Williams, 2000).

Pesticides are toxic in nature and do not differentiate between targeted and non-targeted species, and hence should essentially be subject to safe and judicious use. Due to injudicious and indiscriminate use of pesticides, many accidents have occurred in different parts of Nepal, and presence of pesticides in foods, fruits, vegetables environment and even in mothers milk is a matter of grave concern (FAO/ WHO, 2005).

Of all the pesticides released into the environment every year by human activity, persistent pesticides are among the most dangerous. They are highly toxic, causing an array of adverse effects, notably death, diseases and birth defects among human and animals. Specific effect can include cancer, allergies and hypersensitivity, damage to the central and peripheral nervous systems, reproductive disorders, and disruption of the immune system. (Strict, 1981; Maroni, 1990)

\section{OBJ ECTIVE}

The general objective of the paper is to present the provision of standards setting for the pesticide residue limits in ensuring the food safety. The specific objectives are:

To assess the use of pesticides

\footnotetext{
${ }^{12}$ Deputy Director General, Department of Food Technology and Quality Control. Email:

jiwanlama@gmail.com
} 
To present pesticide residue data in food

To make people aware of pesticide effects on human and environment

To provide the mechanism of setting standards of pesticide residue limits in food

To assess the capability in controlling pesticide residues

\section{METHODOLOGY}

National experience of standards of the pesticide residue limits for ensuring food safety was prepared under the framework of legal provision and secondary data of pesticide used and pesticide residues analysis (AOAC). The sources of secondary data are research papers, annual reports of DFTQC, J ournal of Food Science and Technology Nepal (J FSTN) etc.

\section{PESTICIDES IN NEPAL}

Until the 1950s, Nepalese were unaware of modern chemical pesticides and were dependent upon traditional organic techniques for killing pests. Chemical pesticides were first introduced to this country in 1955 when Paris Green, gamaxone, and nicotine sulphates were imported from USA for malaria control. DDT made its first impact in 1956. This was soon followed by a variety of other organochlorines (1950s), organophosphates (1960s), Carbamates (1970s), and Synthetic pyrethroids (1980s).

The Nepal Malaria Eradication Program (NMEP) in the 1950s was the first major channel to utilize pesticides in Nepal. The chemical pesticides, provide through the grant assistance by USAID, were initially in limited quantity, primarily used for the control of vector-borne diseases. As a result of this program, there was ninety nine percent reductions of malaria cases which was completed in early seventies.

The establishment of Department of Agriculture, initiated the application of chemical pesticides for crop protection during the mid of the 1960s. Since then, the use of pesticides for plant protection has steadily increased. Increasing demands for chemical pesticides resulted in private dealerships selling and distributing pesticides throughout the country.

In 1977, the Nepal Pesticides and Chemical Industries Pvt. Ltd. (NEPCIL) was established in Bahadurgunj to supply BHC dust, malathion, Nepcil parathion among others locally. The Indian representative such as Crop Health Production Ltd., Excel Industries Ltd., Cyanamid India Ltd., Bharat Pulverizing Mills Ltd. were the main suppliers of pesticides in Nepal. Organizations like the Cotton Development Board (CDB) and Nepal Malaria Eradication Programs were also authorized to purchase pesticides from foreign distributors. Presently, Indian Pesticide dealers cross the open border freely, selling pesticides in the Terai region and in major towns of Nepal (Palikhe, 2001).

\section{PREVOUS STUDY ON PESTICIDE RESIDUES}

A total of one thousand and thirty four samples of different food commodities during 19952004 were analyzed for detection of organochlorine (DDT, BHC) and organopohsophorus (malathion, parathion, methyl parathion) pesticide residues. Among all samples analyzed $12.1 \%$ of the total samples were detected with the residues of pesticides which included malathion (3.9\%), BHC (3.1\%), Methyl parathion (2.8\%), DDT (1.8\%) and parathion $(0.3 \%)$. Commodity-wise detection of pesticide residues showed the highest level of contamination in root vegetables (11.9\%) followed by leafy vegetables (10.9\%) (DFTQC, 1995). 


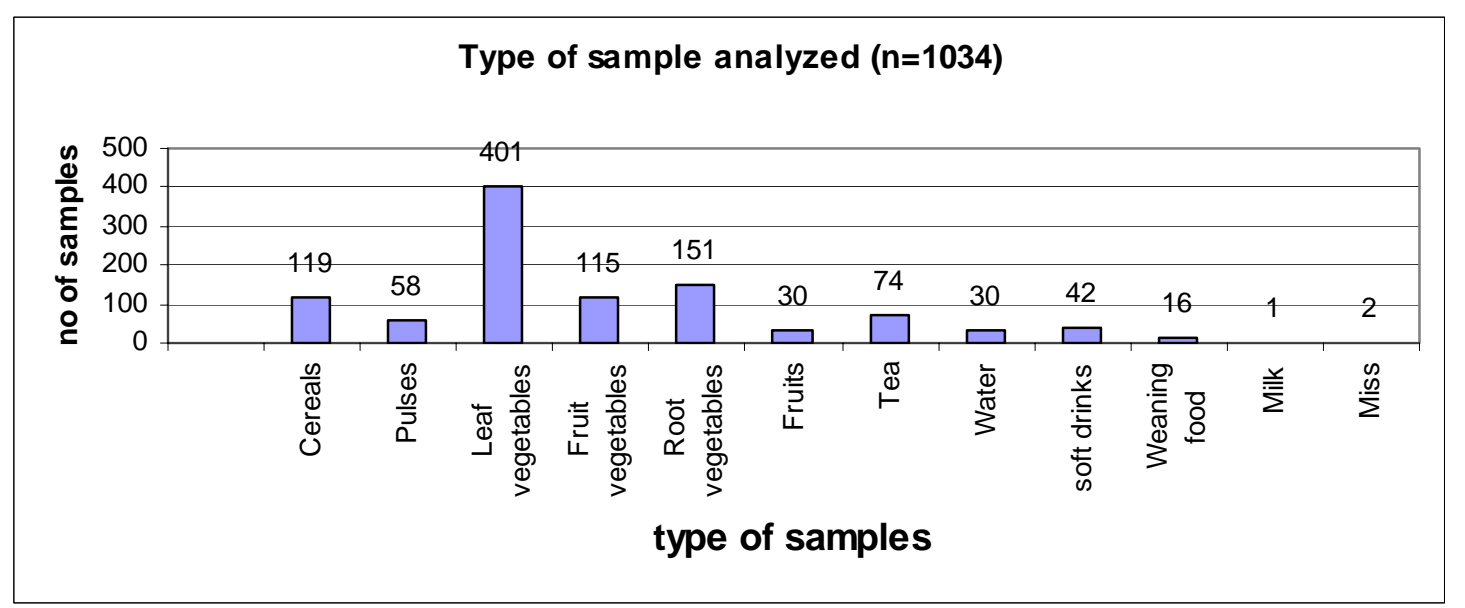

Fig 1: Type of samples analyzed for pesticide residues

\section{RISKS DUE TO PESTICIDE RESIDUES IN HUMAN HEALTH AND ENMRONMENT}

Effect on human health

The adverse health effects of pesticide misuse are a global phenomenon causing an estimated 10,000 illnesses worldwide (Dahal et al., 1994). Thus, they pose potential risks to all human

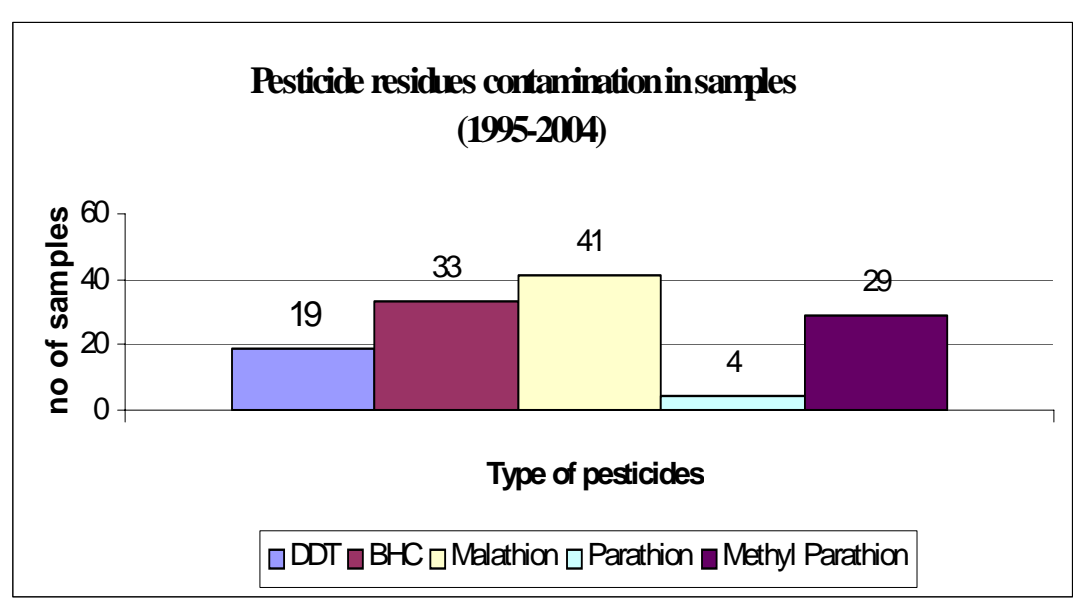
beings. The health cost of pesticide problems can be described as:

1 Acute poisonings of farmers and distributors

2 Chronic health problems due to prolonged exposure to pesticides

3 Pesticide residues on food

Fig 2 : Pesticide residues contamination in food samples

Some acute pesticide poisonings were reported by hospitals in Kathmandu valley. Many of whom were farmers. Fishing bait is another dangerous practice, which is seriously becoming health hazards in Palpa, Chitwan and Dang. Similarly, some of the more acutely toxic substances such as endrin and endosulphan were reportedly used for fishing. Some sporadic cases of fatal pesticide poisoning had been reported in local newspapers (Gorkhapatra, 1989). Several studies show that sometimes even if framers and distributors do not die quickly death from pesticide misuse, they are still at risk of chronic health problems due to their prolonged exposure to pesticides. The study also indicates that long-term exposure to most pesticides causes serious health problems, which may occur months or years after initial exposure. The effect of pesticides such as organochlorine (OC), organophosphorus (OP), carbamates may cause cancer, tumors, birth defects, blood disorders etc. Studies done in the United States 
had shown that farmers were more likely to contract certain kinds of cancer than nonfarmers. The fifty five cancer-causing pesticides had been identified as those leaving the organochlorine such as BHC, DDT, aldrin have long term residual effects than other pesticides. (Giri, 1998).

\section{Effect on environment}

Pesticides, especially the organochlorine and organophosphate tend to persist in the environment, causing several types of damages including lowering of biodiversity, soil contamination, and water contamination. Once released into the environment, pesticides tend to build up in the fatty tissues of living organisms, causing serious harm to the health of species and a potential loss of bio-diversity. Excessive use of persisting pesticides in the fields also have caused surface and underground water contamination are illustrated by records of some international studies. Methyl bromide one of the mostly used pesticides for soil fumigation in many countries have also been identified as the major contributor of ozone depletion. (Giri, 1998)

\section{STANDARDIZATION COMMTTEE OF MRLS ON PESTICIDES RESIDUES}

A food standardization committee is formed to carry out the functions as specified in the Food Act and this Regulation (GoN, 1967). The committee is to set the quality standard and limit of quantity of the food and advice Government of Nepal regarding the quality standard and quantity maintained and observed (Annex-2). The committee may invite, where considered necessary, an expert in the concerned field, to take part, as an observer, in the meeting of the committee. The committee may form, as necessary, a sub-committee for any specific function. The functions, duties, powers and procedures of such sub-committee shall be as specified by the committee. The committee may frame necessary by-laws to set its procedures. Provided, however, that such by-laws shall come into force only upon approval of Government of Nepal. The committee shall liaise with Government of Nepal, generally through the Ministry of Agriculture and Cooperatives. Till 2008, Government of Nepal has set the mandatory pesticide residue limits as per Food Law and Regulation. The name of pesticides, food commodity, and their maximum residue limits (MRLs) are notified for public in Nepal Gazette (Annex-4).

\section{CONCLUSONS AND RECOMMENDATIONS}

Pesticides are the potential health hazards, which have drawn attention of food quality control agencies, certification bodies, international community and trading partners. Due to the lack of regular monitoring scheme of MRL on pesticides, it has affected the export of tea, honey and other food commodities in the recent years. Similarly, the certification of organic foods has faced problem due to the absence of this monitoring scheme.

For the improvement in present situation regarding the pesticide use, pest resistant to pesticides, environmental contamination, and health hazard to farmers as well as the consumers from the toxic chemicals, the following recommendations are suggested.

Farmers or producers of agro-food products should follow good agriculture practices, which takes account of proper use of certified chemicals within the approved amount or limited dose. The misuse and abuse of such chemicals increases the resultant residues problems in food products as well as environmental pollution. Nepal needs to develop NEPAL GAP 
considering the benchmark standard of GLOBAL GAP. IPM, the tool to help farmers to get rid of pesticides, should be implemented to the field level with intensive programs.

Pesticide residues is arising a prominent issue on the food safety and environmental pollution. In order to control the resultant residue problem in foods and promotion of food trade in international market, a national pesticide residues monitoring program should be implemented.

There should be a coordinating team of public private partnership for close monitoring of appropriate use of pesticides at the field level.

A regular training / workshop about the use and safety measures of pesticide should be given to farmers, retailers, distributors and all the pesticide workers. Multimedia awareness activities in local language should be massively conducted.

Laboratory capacities and facilities should be strengthened in order to cope the newly emerged challenges of contaminants as wells as harmonization of analytical methods for settlement of dispute in the reliability of the results.

The gap between the availability and the requirement is very wide, which demands the exchange visits, training and other academic opportunities in the field of food safety and quality as well as laboratory analysis.

In order to protect the consumers against the biological, chemical, and environmental contamination of food, the food safety should encompass the control over all stages of food production, processing and distribution of foods. There is need of development of the ability to follow the movement of food through specified stages of production, processing and distribution.

Scientific evaluation of potential adverse effects resulting from human exposure to food borne hazards. Risk analysis is relatively new applied science based on sound scientific footing to protect consumer's health by Appropriate Level of Protection (ALOP). Necessary data and information for the food standardization should be base on risk analysis of particular food commodity.

Export potential products have been reduced in current year due to pesticide residues and other inorganic residues that comes from agricultural practice (J NSF, 2007). So horizontal standards of pesticide residues should be enforced in the agro products especially those for exportable products to facilitate trade as well as for the production of safe food.

Codex Contact Point and National Codex Committee should be strengthened with the participation from wide range of stakeholders such as industry, academics and consumers, for the development of national database and evaluation of the implications of international food standards.

There should be a permanent regional forum among SAARC countries on Food Safety and Quality to make common regional agendas in issues related to food trade, standards, quality and safety in international forum and Codex System. 
There is thrust of resources and assistantship to attain the international and regional food safety forum and meetings to upgrade the capacity building.

\section{REFERENCES}

Dahal, L., S. L. Baker and B.K. Gyawali, 1992. Promoting proper use of Pesticides in Nepal, AREP Consultancy report no. 12, Winrock International, Nepal.

DFTQC, 2004. Department of Food Technology and Quality Control, Annual Report, Nepal.

FAO/ WHO, 2005. Food Safety Risk Analysis, Part II, Case Studies, Food and Agricultural Organization of the United Nations (FAO), World Health Organization (WHO).

GON, 1967. Food Act 1967. Government of Nepal.

GON, 1970. Food Regulation 1970. Government of Nepal.

Giri, N.P., 1998. Pesticides Pollution in Vegetable crop in Kathmandu Valley, M. Sc. thesis, Department of Zoology, Tribhuvan University, Nepal.

Gorkhapatra, 1989. Gorkhapatra daily (Nepali), 7 May 1989.

Maroni, H. M., 1990. Studying the effects of pesticides on humans (International Commission on Occupational Health). 1990. Proceedings of the 9th International workshop, 2-4 May 1990, International Centre for Pesticide Safety, Busto Garolfo, Milan, Italy. ICOH, Geneva, Switzerland.

Palikhe, B. R., 2001. Pesticides pollution management in Nepal: In harmony with nature, Agriculture and Environment communication issue, Min. of Agri. and Coop., Kathmandu, Nepal.

Strict, J.C., 1981. Pesticide and the immune system. In: R.P. Sharma (ed.), Immunologic Considerations in Toxicology Vol.1. CRC Press.

Wassemann, M. D., 1972. Effects of Organochorine insecticides on homeostatic and immunologic process, fate of pesticides in the environment, Gordon and Breach London.

Williams, M., 2000. Nutrition and the Environment ACC SCN 21 Report, Geneva Switzerland, 2000

\section{ANNEXES}

Annex 1: Standardization committee of maximum residue limits (MRLs) on pesticides

\begin{tabular}{r|l|l}
\hline 1 & Secretary, Ministry of Agriculture and Cooperatives & Chairperson \\
\hline 2 & Representative, Ministry of Law and J ustice & Member \\
3 & Representative, Ministry of Industries & Member \\
4 & Representative, Ministry of Commerce & Member \\
5 & Representative, Ministry of Supplies & Member \\
6 & Representative, Ministry of Home & Member \\
7 & Representative, Ministry of Health & Member \\
8 & Representative, Kathmandu Metropolitan City & Member \\
9 & Food industry entrepreneur (1) nominated by Fed. Industries and Com. & Member \\
10 & As nominated by the Ministry of Supplies among food consumers (1) & Member \\
11 & Director General, Department of Food Technology and Quality Control & Mem. secretary \\
\hline
\end{tabular}


Annex-2

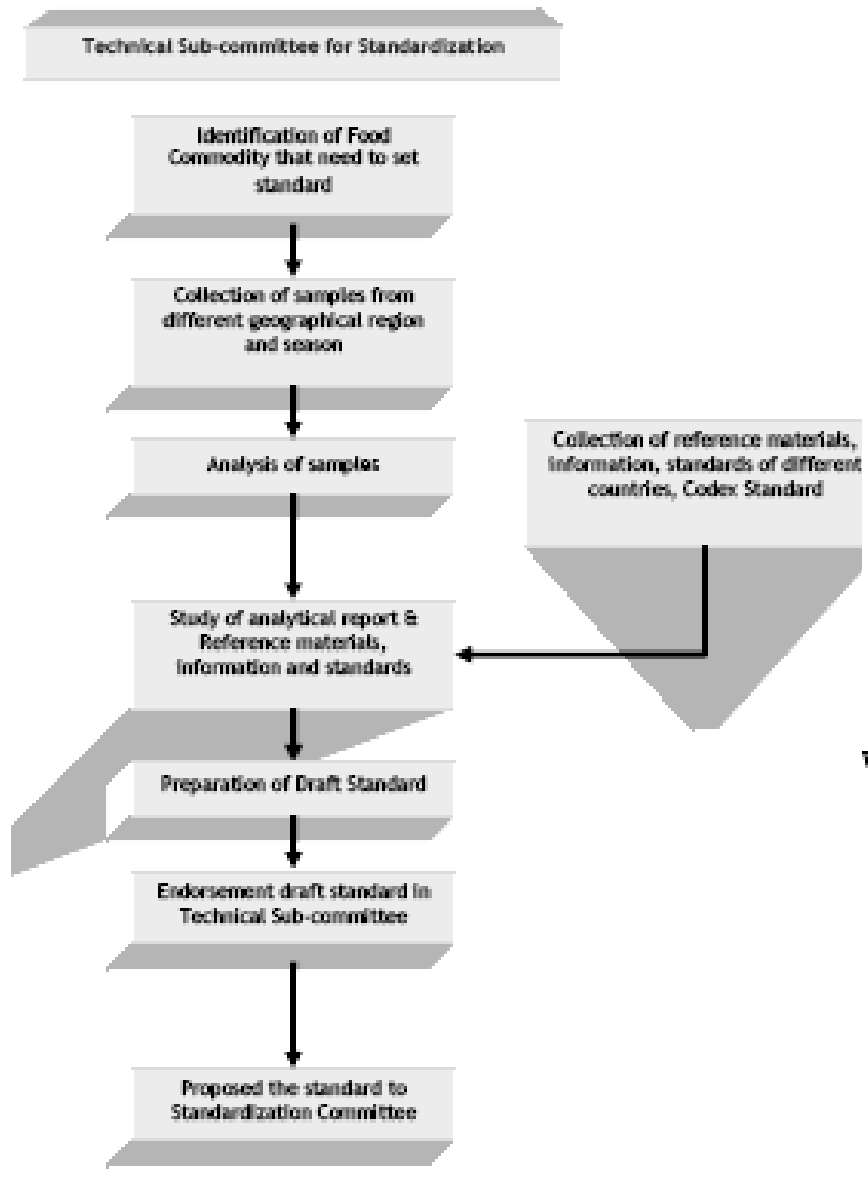

Annex-3

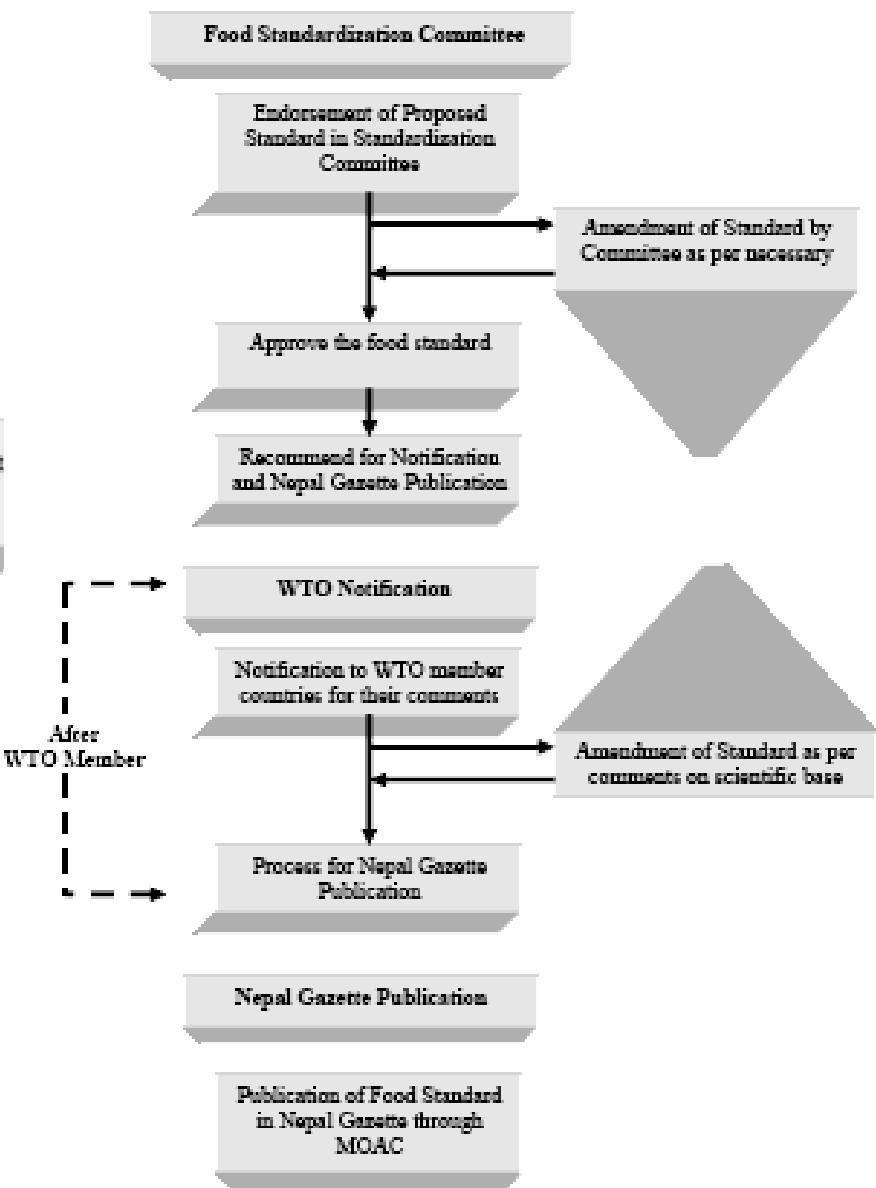

Annex-4: Food commodity and maximum pesticide residue limits (MRLs)

\begin{tabular}{l|l|c}
\hline \multicolumn{1}{c|}{ Pesticide type } & \multicolumn{1}{|c}{ Food commodity } & Max residue limit $(\mathrm{mg} / \mathrm{kg})$ \\
\hline 1. Aldrin, dieldrin & Food Grains, legumes and pulses & 0.01 \\
& Skimmed Milk Powder Whole Milk Powder & 0.15 \\
2. Benomyl & Processed Drinking Water & 0.03 \\
3. Carbaryl & Skimmed Milk Powder & 0.1 \\
4. Carbendazim & Whole Milk Powder & 0.1 \\
& Food Grains, legumes and pulses & 1.5 \\
5. Carbofuran & Food Grains, legumes and pulses & 0.50 \\
& Skimmed Milk Powder & 0.1 \\
& Whole Milk Powder & 0.1 \\
6. Chlordane & Food Grains, legumes and pulses & 0.10 \\
& Skimmed Milk Powder & 0.1 \\
& Whole Milk Powder & 0.1 \\
7. Chlorfenvinphos & Food Grains, legumes and pulses & 0.02 \\
& Skimmed Milk Powder & 0.05 \\
8. Chlorpyrifos & Whole Milk Powder & 0.05 \\
& Processed Drinking Water & 0.03 \\
& Food Grains, legumes and pulses & 0.025 \\
& Skimmed Milk Powder & 0.2 \\
& Whole Milk Powder & 0.2 \\
& Food Grains, legumes and pulses & 0.05 \\
& Skimmed Milk Powder & 0.01 \\
& Whole Milk Powder & 0.01 \\
\hline
\end{tabular}




\begin{tabular}{|c|c|c|}
\hline Pesticide type & Food commodity & Max residue limit $(\mathrm{mg} / \mathrm{kg})$ \\
\hline 9. Cypermethrin & Skimmed Milk Powder & 0.05 \\
\hline 10. DDT & $\begin{array}{l}\text { Whole MIlK Powder } \\
\text { Food Grains, legumes and pulses }\end{array}$ & $\begin{array}{r}0.05 \\
\text { Absent }\end{array}$ \\
\hline & $\begin{array}{l}\text { Skimmed Milk Powder } \\
\text { Whole Milk Powder }\end{array}$ & $\begin{array}{l}0.02 \\
0.02\end{array}$ \\
\hline & Processed Drinking Water & \\
\hline 11. $2-4 \mathrm{D}$ & Food Grains, legumes and pulses & 0.01 \\
\hline & Whole Milk Powder & 0.05 \\
\hline 12. Diazinon & $\begin{array}{l}\text { Processed Drinking Water } \\
\text { Food Grains leaumes and pulses }\end{array}$ & $\begin{array}{r}100 \\
0.05\end{array}$ \\
\hline 13. Dicamethrin/ & Food Grains, legumes and pulses & 0.50 \\
\hline 14. Dichlorvos & Food Grains, lequmes and pulses & 1.0 \\
\hline $\begin{array}{l}\text { 15. Dithiocarbamates } \\
\text { 16. Edifenphos }\end{array}$ & $\begin{array}{l}\text { Food Grains, legumes and pulses } \\
\text { Skimmed Milk Powder }\end{array}$ & $\begin{array}{r}0.2 \\
0.05\end{array}$ \\
\hline 17. Ethion & $\begin{array}{l}\text { Whole Milk Powder } \\
\text { Skimmed Milk Powder }\end{array}$ & $\begin{array}{r}0.05 \\
0.5\end{array}$ \\
\hline - & Whole Milk Powder & 0.5 \\
\hline 18. Fenthion & $\begin{array}{l}\text { Food Grains, legumes and pulses } \\
\text { Skimmed Milk Powder }\end{array}$ & $\begin{array}{l}0.10 \\
0.01\end{array}$ \\
\hline & Whole Milk Powder & 0.01 \\
\hline 19. Fenitrothion & $\begin{array}{l}\text { Food Grains, legumes and pulses } \\
\text { Skimmed Milk Powder }\end{array}$ & $\begin{array}{l}0.02 \\
0.05\end{array}$ \\
\hline 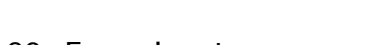 & Whole Milk Powder & 0.05 \\
\hline 20. Fenvalerate & Skimmed Milk Powder & 0.05 \\
\hline 21. Heptochlor & Food Grains, legumes and pulses & 0.01 \\
\hline & $\begin{array}{l}\text { Whole Milk Powder } \\
\text { Processed Drinking Water }\end{array}$ & $\begin{array}{r}0.15 \\
0.1\end{array}$ \\
\hline 22. Hexachlorobenzene & Processed Drinking Water & 0.01 \\
\hline $\begin{array}{l}\text { 23. Hydrogen Cyanide } \\
\text { 24. Hydrogen Phosphide }\end{array}$ & $\begin{array}{l}\text { Food Grains, legumes and pulses } \\
\text { Food Grains, legumes and pulses }\end{array}$ & $\begin{array}{r}37.05 \\
0.02\end{array}$ \\
\hline 25. Inorganic Bromide & Food Grains, legumes and pulses & $\begin{array}{l}25.0 \\
0.01\end{array}$ \\
\hline Zo. Limuante & $\begin{array}{l}\text { Skimmed Milk Powder } \\
\text { Whole Milk Powder }\end{array}$ & $\begin{array}{l}0.01 \\
0.01\end{array}$ \\
\hline & Processed Drinking Water & 3.0 \\
\hline $\begin{array}{l}\text { 27. Malathion } \\
\text { 28. Monocrotophos }\end{array}$ & $\begin{array}{l}\text { Food Grains, legumes and pulses } \\
\text { Food Grains, legumes and pulses } \\
\text { Skimmed Milk Powder }\end{array}$ & $\begin{array}{r}4.0 \\
0.025 \\
0.02\end{array}$ \\
\hline & Whole Milk Powder & 0.02 \\
\hline 29. Oxydemeton methyl & Food Grains, legumes and pulses & 0.02 \\
\hline $\begin{array}{l}\text { 30. Paraquat dichloride } \\
\text { 31. Phenthoate }\end{array}$ & $\begin{array}{l}\text { Food Grains, legumes and pulses } \\
\text { Food Grains, legumes and pulses }\end{array}$ & $\begin{array}{r}0.025 \\
0.05\end{array}$ \\
\hline & $\begin{array}{l}\text { Skimmed Milk Powder } \\
\text { Whole Milk Powder }\end{array}$ & $\begin{array}{l}0.01 \\
0.01\end{array}$ \\
\hline 32. Phorate & Food Grains, legumes and pulses & 0.05 \\
\hline & Skimmed Milk Powder & 0.01 \\
\hline 33. Phosphamindon & Food Grains, legumes and pulses & 0.05 \\
\hline 34. Pirimiphos-methyl & Skimmed Milk Powder & \\
\hline 35. Pyrethrins & Food Grains, legumes and pulses & Absence \\
\hline 36. Trichlorfon & Food Grains, legumes and pulses & 0.05 \\
\hline
\end{tabular}

